\title{
EVALUASI KELENGKAPAN PENANDAAN DAN KESESUAIAN NOMOR NOTIFIKASI KOSMETIKA YANG DIPERDAGANGKAN DI SALAH SATU SWALAYAN DI KOTA YOGYAKARTA
}

\section{LABELING COMPLETENESS EVALUATION AND NOTIFICATION NUMBERS SUITABILITY OF COSMETICS SOLD IN ONE OF THE SUPERMARKETS IN YOGYAKARTA CITY}

\author{
Muhammad Muhlis ${ }^{1}$, Triatmi Yanuartati ${ }^{1}$ \\ ${ }^{1}$ Fakultas Farmasi Universitas Ahmad Dahlan, Yogyakarta \\ Korespondensi : muhlis3@yahoo.co.id
}

\begin{abstract}
ABSTRAK
Untuk melindungi masyarakat dari penggunaan kosmetika yang tidak memenuhi persyaratan mutu, keamanan dan kemanfaatan, maka pemerintah mensyaratkan kosmetika yang beredar harus memenuhi persyaratan teknis meliputi penandaan yang di dalamnya terdapat nomor notifikasi. Penelitian ini bertujuan untuk mengetahui kelengkapan penandaan dan kesesuaian nomor notifikasi kosmetika yang tergolong dalam kategori sediaan perawatan kulit, sediaan pewarna rambut, sediaan rias mata, sediaan rias wajah, dan sediaan kuku yang diperdagangkan di salah satu swalayan di Yogyakarta.

Penelitian ini digunakan metode observasional. Data penandaan dan nomor notifikasi terhadap lima kategori kosmetika yang kemudian dievaluasi dengan ketentuan kosmetika yang berlaku dan termuat dalam Peraturan Kepala BPOM RI.

Hasil penelitian didapatkan jumlah total 1.083 produk kosmetika dari lima kategori yang dievaluasi, kosmetika yang tidak memenuhi persyaratan kelengkapan penandaan sejumlah 87\%. Ketidaklengkapan penandaan didominasi oleh tidak adanya informasi peringatan/keterangan lain pada produk. Diketahui sejumlah $42 \%$ kosmetika disertai dengan nomor notifikasi yang tidak sesuai dengan ketentuan yang berlaku karena telah habis masa berlakunya dan harus diperpanjang untuk dapat diedarkan kembali. Disimpulkan bahwa hanya sebesar 13\% kosmetika yang telah memenuhi persyaratan kelengkapan penandaan dan sejumlah 58\% kosmetik telah disertai dengan nomor notifikasi yang sesuai dengan ketentuan yang berlaku.
\end{abstract}

Kata kunci : kosmetika, penandaan, nomor notifikasi.

To protect the public from the use of cosmetics that do not meet quality, safety, and usefulness requirements, the government requires that cosmetics in circulation must meet technical requirements including marking in which there is a notification number. This study aims to determine the completeness of the marking and appropriateness of cosmetic notification numbers belonging to the categories of skincare preparations, hair dye preparations, eye make-up preparations, facial makeup preparations, and nail preparations traded at one of the supermarkets in Yogyakarta.

This study used an observational method. The marking data and the notification number of the five cosmetic categories are then evaluated by the applicable cosmetics provisions and contained in the Regulation of the Head of BPOM RI.

The results showed a total of 1,083 cosmetic products from the five categories evaluated, cosmetics that did not meet the marking requirements were $87 \%$. The incomplete marking is dominated by the absence of warning information / other information on the product. It is known that $42 \%$ of cosmetics are accompanied by a notification number that is not by the applicable provisions because it has expired and must be extended to be circulated again. It was concluded that only $13 \%$ of cosmetics had fulfilled the marking requirements and $58 \%$ of cosmetics had been accompanied by a notification number by applicable regulations.

Keywords: cosmetics, labeling, notification numbers.

\section{PENDAHULUAN}

Kosmetik adalah bahan atau sediaan yang dimaksudkan untuk digunakan pada bagian luar tubuh manusia (epidermis, rambut, kuku, bibir, dan organ genital bagian luar) atau gigi atau mukosa mulut 
terutama membersihkan, mewangikan, mengubah penampilan dan atau memperbaiki bau badan atau melindungi atau memelihara tubuh pada kondisi baik (BPOM RI, 2003), Kosmetika yang beredar harus memenuhi persyaratan teknis meliputi persyaratan keamanan, kemanfaatan, mutu, penandaan dan klaim. Penandaan berisi informasi mengenai kosmetika secara lengkap, obyektif, dan tidak menyesatkan (BPOM RI, 2015). The European Regulation 1223/2009, telah menetapkan pula mengenai persyaratan penandaan pada label kosmetik (Lionetti dan Rigano, 2018). Kosmetika yang beredar tidak boleh menyebabkan kerusakan pada manusia dengan demikian harus aman digunakan. Aman disini adalah aman pada penggunaan yang dapat diperkirakan sebelumnya termasuk durasi dan, masa berlaku, cara penggunaan, perakitan bahan/alat, semuanya itu tidak menimbulkan risiko atau hanya risiko minimum jika dilakukan sesuai dengan penggunaan produk (Pauwels dan Rogiers, 2010).

Kosmetika yang tidak memenuhi persyaratan penandaan label dapat menyebabkan penggunaan yang tidak tepat sehingga dapat memberikan pengaruh yang negatif bagi pengguna (Pangaribuan, 2017), pengaruh negatif termasuk diantaranya dermatitis, penyakit dermatitis akibat kosmetik terbanyak tahun 2017 sebanyak 8.6\% dari total kunjungan pasien dermatitis kontak di divisi alergi RSUD Dr. Soetomo Surabaya. Bahan penyebab terbanyak yang dilaporkan adalah krim pagi. Manifestasi klinis terbanyak bentuk makula eritematosa disertai dengan rasa gatal dengan eliminasi bahan penyebab sebagai penatalaksanaan utama pada DKA Dermatitis Kontak Alergi) akibat kosmetik (Rubianti dan Prakoeswa, 2019). Dalam survei yang diterbitkan pada tahun 2006, Sebanyak 3.474 pengguna kosmetik diwawancarai, 848 di antaranya pernah mengalami efek samping kosmetik. Separuh wanita yang mengalami efek samping kosmetik tidak mengikuti nasihat medis, juga tidak berkonsultasi dengan apoteker (Kotby dkk., 2020). Penelitian yang dilakukan Susantri dkk. (2018) melaporkan bahwa BBPOM Banda Aceh mengadakan razia yang digelar pada bulan Oktober 2016 dan ditemukan banyak kosmetik ilegal yang beredar, penyitaan terbesar ditemukan di tiga kabupaten di Aceh, yaitu Kabupaten Aceh Timur, Aceh Jaya dan Aceh Barat Daya, ditemukan sebanyak 1.135 pieces dari 113 jenis kosmetik ilegal, Kosmetik dan produk perawatan kulit yang digunakan dengan cara yang salah, dapat menimbulkan efek samping cukup sulit karena munculnya efek samping yang lemah sering tidak menjadi saran medis. Efek samping berasal dari penggunaan kosmetik menimbulkan risiko kesehatan terutama karena paparan banyak zat kimia. Konsekuensinya dapat berupa reaksi hipersensitivitas ringan hingga anafilaksis atau bahkan toksisitas yang mematikan (Pereira dan Pereira, 2018).

Munculnya toko ritel modern dan kebutuhan konsumen terhadap tempat berbelanja yang nyaman sehingga bermunculan perusahaan dagang yang bergerak dibidang perdagangan ritel yang berbentuk minimarket maupun swalayan. Para peritel menawarkan berbagai hal positif antara lain kenyamanan saat berbelanja, keamanan, kemudahan, variasi produk yang semakin beragam, kualitas produk yang terus meningkat dan tentu saja harga produk yang menjadi lebih murah sehingga dapat mempengaruhi keputusan pembelian konsumen, (Irawati, 2014) sehingga untuk pemenuhan kebutuhan sehari-hari termasuk kosmetik, swalayan lebih dipilih oleh masyarakat dengan tawaran persaingan harga yang ketat serta kenyamanan dalam berbelanja (Maria dkk., 2002).

\section{METODE PENELITIAN}

Metode penelitian ini adalah observasional mengenai evaluasi kelengkapan Penandaan dan kesesuaian Nomor Notifikasi produk Kosmetika. Sampel penelitian ini adalah kosmetika yang tergolong dalam kategori sediaan perawatan kulit, sediaan pewarna rambut, sediaan rias mata, sediaan rias wajah, dan sediaan kuku yang diperdagangkan di salah satu Swalayan di Kota Yogyakarta Sebanyak 1083 produk Kosmetika.

Data dikumpulkan dengan metode observasional menggunakan lembar checklist, yang terdiri dari Nama kosmetika, Kegunaan, Cara penggunaan, Komposisi, Nama dan negara produsen, Nama dan alamat lengkap pemohon notifikasi, Ukuran, isi, atau berat bersih, Nomor bets, Tanggal kedaluwarsa, Nomor notifikasi, Peringatan/perhatian dan keterangan lain, jika dipersyaratkan. Pengumpulan data mengenai produk Kosmetika yang tergolong dalam kategori sediaan perawatan kulit, sediaan pewarna rambut, sediaan rias mata, sediaan rias wajah, dan sediaan kuku yang diperdagangkan di salah satu Swalayan di Yogyakarta serta Penandaan dan Nomor Notifikasi dari produk-produk Kosmetika tersebut diperoleh dengan cara observasi dengan bantuan kamera ponsel yang disalin ke dalam lembar pengumpulan data. 
Data produk-produk Kosmetika yang tergolong dalam kategori sediaan perawatan kulit, sediaan pewarna rambut, sediaan rias mata, sediaan rias wajah, dan sediaan kuku yang diperdagangkan di salah satu Swalayan di Kota Yogyakarta dianalisis secara deskriptif mengikuti ketentuan Penandaan serta Nomor Notifikasi Kosmetika sesuai dengan Persyaratan Teknis Kosmetika menurut Peraturan Kepala Badan Pengawas Obat Dan Makanan Republik Indonesia Nomor 19 Tahun 2015.

\section{HASIL DAN PEMBAHASAN}

\section{A. Kelengkapan Penandaan Produk Kosmetika}

Sebanyak 1083 produk Kosmetika yang menjadi objek penelitian yang terbagi menjadi lima kategori yaitu sediaan perawatan kulit 97 item, sediaan pewarna rambut 83 item, sediaan rias mata 158 item, sediaan rias wajah 706 item, dan sediaan kuku 39 item.

Produk kosmetika yang menjadi objek penelitian dievaluasi kelengkapan penandaannya dengan keharusan mencantumkan informasi mengenai kosmetika secara lengkap, yang terdiri dari:

1. Nama kosmetika;

2. Kegunaan;

3. Cara penggunaan;

4. Komposisi;

5. Nama dan negara produsen;

6. Nama dan alamat lengkap pemohon notifikasi;

7. Ukuran, isi, atau berat bersih;

8. Nomor bets;

9. Tanggal kedaluwarsa;

10. Nomor notifikasi;

11. Peringatan/perhatian dan keterangan lain, jika dipersyaratkan

Tabel I. Hasil Evaluasi Kelengkapan Penandaan Produk Kosmetika (\%)

\begin{tabular}{lccccccccccc}
\hline \multicolumn{1}{c}{ Kategori } & $\mathbf{a}$ & $\mathbf{b}$ & $\mathbf{c}$ & $\mathbf{d}$ & $\mathbf{e}$ & $\mathbf{f}$ & $\mathbf{g}$ & $\mathbf{h}$ & $\mathbf{i}$ & $\mathbf{j}$ & $\mathbf{k}$ \\
\hline Sediaan perawatan kulit & 100 & 100 & 98 & 100 & 100 & 100 & 100 & 100 & 100 & 100 & 66 \\
Sediaan pewarna rambut & 100 & 100 & 100 & 100 & 100 & 100 & 96 & 100 & 100 & 100 & 65 \\
Sediaan rias mata & 100 & 100 & 11 & 100 & 100 & 100 & 100 & 100 & 100 & 100 & 12 \\
Sediaan rias wajah & 100 & 100 & 14 & 100 & 100 & 100 & 87 & 87 & 100 & 100 & 14 \\
Sediaan kuku & 100 & 100 & 36 & 100 & 90 & 90 & 100 & 87 & 100 & 100 & 100 \\
\hline
\end{tabular}

Keterangan :

a. Nama kosmetika

b. Kegunaan

g. Nomor bets

c. Cara penggunaan

h. Ukuran, isi atau berat bersih

d. Komposisi

i. Tanggal kedaluwarsa

e. Nama dan negara produsen

f. Nama dan alamat lengkap pemohon notifikasi

j. Nomor notifikasi

k. Peringatan/perhatian dan keterangan lain

Sediaan perawatan kulit sebanyak 97 item meliputi krim malam (night cream), krim siang (day cream) anti jerawat, krim pencerah kulit sekitar mata [eye cream (whitening)], pencerah kulit (skin lilghtener), dan anti aging cream menjadi bahan evaluasi mengenai kelengkapan penandaan serta kesesuaian nomor notifikasi yang tertera pada masing-masing produk, seperti terlihat pada Tabel I, sediaan perawatan kulit, diperoleh data bahwa sejumlah $66 \%$ atau sebanyak 64 item dari total keseluruhan produk diketahui disertai dengan penandaan yang lengkap dan sejumlah 34\% sisanya atau sebanyak 33 item adalah produk dengan pencantuman penandaan yang tidak lengkap. Ketidaklengkapan penandaan pada 33 produk kosmetika yaitu pada informasi cara penggunaan dan peringatan/perhatian. Kelengkapan informasi pada label kosmetika merupakan hak konsumen (Susantri dkk., 2018), ketidaklengkapan ini dapat menyebabkan kesalahan dalam penggunaan kosmetika (Sukristiani dkk., 2014).

Sediaan pewarna rambut (hair colour) dan pemudar warna rambut (hair lightener) sejumlah 83 item yang menjadi objek dalam evaluasi diperolehan data hasil evaluasi yang telah dilakukan, sejumlah 65\% (54 item) produk sediaan pewarna rambut disertai dengan informasi penandaan yang lengkap sedangkan sejumlah 35\% (29 item) produk ditemukan bahwa penandaan yang dimiliki tidak dilengkapi semua informasi 
yang diperlukan pada produk kosmetik. Informasi mengenai kosmetika yang tidak tertera pada produk berupa nomor bets dan peringatan/perhatian.

Sediaan rias mata (eye shadow) sebanyak 158 item hasil evaluasi ditemukan bahwa produk yang disertai mencantumkan cara penggunaan hanya 11\% (17 item) dan yang mencantumkan peringatan/perhatian hanya 12\% (19 item), ketidak lengkapan ini dapat menyebabkan kesalahan dalam penggunaan dan menimbulkan resiko efek samping.

Sediaan rias wajah yang menjadi objek evaluasi kelengkapan Penandaan berupa pemerah pipi (blush on), make-up kit, lip color, lip gloss, dan lip care sejumlah 706 item. Dari tabel I dapat dilihat bahwa hanya sejumlah 14\% (99 item) yang mencantumkan cara penggunaan, 87\% (614 item) yang mencantumkan nomer batch dan volume sediaan, $14 \%$ (99 item)mencantumkan peringatan/perhatian. Tidak tercantumnya nomer batch dapat menyebabkan produk tersebut tidak dapat dilacak jika terjadi permasalah pada produknya, fihak produsen tidak dapat merunut terjadi kesalahan yang mana pada produksinya dan tidak dapat mengetahui sebaran wilayah produk tersebut.

Untuk sediaan kuku, pewarna kuku (nail color) sebanyak 39 item menjadi objek yang dievaluasi kelengkapan penandaannya. Pada tabel I ditemukan bahwa 36\% yang mencantumkan cara penggunaan, $90 \%$ mencantumkan nama negara dan alamat produsen, $87 \%$ mencantumkan volume sediaan. Produk yang tidak mencantumkan nama negara produsen serta alamat pabrik 10\% (4 item). Ketidaklengkapan ini akan menyulitkan dalam penerbitan notifikasi dan pelacakan produk jika terjadi permasalahan dalam peredarannya.

Dari seluruh sampel sejumlah 1083 hanya 146 produk (13\%) yang mencantumkan secara lengkap tentang kelengkapan Penandaannya sesuai dengan Peraturan Kepala Badan Pengawas Obat Dan Makanan. 87\% produk tidak mencantumkan secara lengkap yang tersebar pada Cara penggunaan, Nama dan negara produsen, Nama dan alamat lengkap pemohon notifikasi, Nomor bets, Ukuran, isi atau berat bersih, Peringatan/perhatian dan keterangan lain.

\section{B. Evaluasi Kesesuaian Nomor Notifikasi Kosmetika}

Dari sejumlah 1.083 produk kosmetika, semua produk telah mencantumkan nomer notifikasi seperti nampak pada tabel I, 58\% atau sebanyak 630 nomor notifikasi sesuai dengan peraturan yang berlaku sedangkan sejumlah $42 \%$ terdiri dari 451 produk dengan nomor notifikasi yang telah habis masa berlakunya dan 2 (dua) produk masih menggunakan nomor notifikasi dengan aturan lama. Berdasarkan peraturan BPOM RI nomor notifikasi hanya berlaku selama tiga tahun.

Tabel II. Hasil Evaluasi Kesesuaian Nomor Notifikasi Kosmetika (dalam \%)

\begin{tabular}{lcccccc}
\hline \multicolumn{1}{c}{ Kategori } & jumlah & A & B & C & D & E \\
\hline Sediaan perawatan kulit & 97 & 100 & 100 & 63 & 100 & 100 \\
Sediaan pewarna rambut & 83 & 100 & 100 & 81 & 100 & 100 \\
Sediaan rias mata & 158 & 99 & 99 & 58 & 99 & 99 \\
Sediaan rias wajah & 706 & 100 & 100 & 55 & 100 & 100 \\
Sediaan kuku & 39 & 100 & 100 & 59 & 100 & 100 \\
\hline
\end{tabular}

Keterangan :
A : Kode Benua
D : Jenis Produk
B : Kode Negara
E : Nomor Urut Notifikasi
C : Tahun Notifikasi

Penomeran notifikasi terdiri dari dua huruf awal yang menunjukkan benua, diikuti 11 angka yang memiliki makna sebagai berikut :

1. Dua angka pertama menunjukkan kode negara,

2. Dua angka kedua tahun notifikasi,

3. Dua angka ketiga menunjukkan jenis produk, dan

4. Lima angka terakhir menunjukkan nomor urut notifikasi (Mita dkk., 2017).

Produk sediaan perawatan kulit (97 produk) pada tabel II, hanya 63\% yang tahun Notifikasinya masih berlaku, sedangkan 37\% (36 produk) dengan nomor notifikasi yang telah kedaluwarsa. Untuk dapat diedarkan kembali, maka nomor notifikasi produk harus segera diperbaharui.

Produk sediaan pewarna rambut (83 produk), sejumlah 81\% (67 produk) disertai nomor notifikasi yang sesuai dengan ketentuan yang berlaku. Sejumlah $19 \%$ (16 produk) disertai nomor notifikasi yang telah habis masa berlakunya sehingga harus segera diperbaharui untuk dapat diedarkan kembali. 
Produk sediaan rias mata (158 produk) ditemukan sejumlah 58\% (91 produk) memiliki nomor notifikasi yang telah sesuai dengan ketentuan yang berlaku dan sejumlah $42 \%$ (67 produk) dengan nomor notifikasi yang telah habis masa berlakunya. Dari evaluasi yang telah dilakukan, diperoleh data bahwa pada 2 produk kosmetika (1\%) sediaan rias mata diketahui masih disertai dengan nomor notifikasi dengan ketentuan lama sehingga tidak hanya telah habis masa izin notifikasi, tetapi untuk kode benua, kode negara, jenis produk serta nomor urut notifikasi produk tersebut tidak sesuai dengan ketentuan baru yang berlaku pada saat ini.

Sediaan rias wajah sejumlah 706 produk, 55\% menggunakan notifikasi yang masih berlaku dan 45\% (318 produk) telah habis masa berlakunya.

Sediaan kuku sebanyak 39 produk, 59\% menggunakan notifikasi yang masih berlaku dan 41\% (16) produk telah habis masa berlakunya.

Permohonan pembaharuan Notifikasi untuk Kosmetika yang telah habis masa berlakunya, diajukan paling lama 1 (satu) bulan sebelum habis masa berlaku notifikasi (DEPKES RI, 2010). Jika permohonan pembaharuan notifikasi telah disetujui oleh Kepala BPOM maka, produk kosmetika dengan Nomor Notifikasi yang telah habis masa berlakunya dapat ditarik untuk pembaharuan nomor notifikasi.

\section{KESIMPULAN}

Berdasarkan hasil evaluasi diperoleh data bahwa Kosmetika yang tidak sesuai dengan kelengkapan Penandaan yang dipersyaratkan melalui Peraturan Kepala Badan Pengawas Obat Dan Makanan Republik Indonesia Nomo 19 Tahun 2015 diketahui sebanyak 146 produk (13\%) disertai dengan informasi penandaan secara lengkap sedangkan 937 produk (87\%) dari total 1.083 produk yang tidak dilengkapi beberapa informasi mengenai produk yang harus disertakan. Hasil evaluasi mengenai kesesuaian nomor notifikasi kosmetika diperoleh data sebanyak 630 produk (58\%) disertai dengan nomor notifikasi yang sesuai dengan ketentuan yang berlaku sedangkan 453 produk (42\%) disertai nomor notifikasi yang telah habis masa berlakunya.

\section{DAFTAR PUSTAKA}

BPOM RI., 2003, Keputusan Kepala Badan Pengawas Obat Dan Makanan Republik Indonesia Nomor Hk.00.05.4.1745 Tentang Kosmetik, Jakarta.

BPOM RI., 2015, Peraturan Kepala Badan Pengawas Obat Dan Makanan Republik Indonesia Nomor 19 Tahun 2015 Tentang Persyaratan Teknis Kosmetik, Jakarta.

DEPKES RI., 2010, Peraturan Menteri Kesehatan Republik Indonesia Nomor 1176/Menkes/Per/VIII/2010 Tentang Notifikasi Kosmetika, Jakarta.

Irawati, W. 2014. Pengaruh Citra Toko terhadap Keputusan Pembelian pada Amanah Swalayan Rengel. Jurnal Pendidikan Tata Niaga (JPTN), 2(2).

Kotby, F., Beayari, S., Alsalmi, K., Sulaimani, A., Alharbi, A., dan Al-Abdrabbuh, D. 2020. Knowledge and practice of women toward the adverse effects of cosmetics in Saudi Arabia. Int J Med Dev Ctries, 4(1): 113-117.

Lionetti, N., \& Rigano, L. 2018. Labeling of Cosmetic Products. Cosmetics, 5(1): 22.

Maria, S., Prihanto, F. X., dan Secapramana, L. V. H. 2002. Hubungan Citra Toko dengan Kepuasan Konsumen pada Pasar Swalayan BP Surabaya. Unitas, 11(1): 65-77.

Mita, S. R., Husni, P., dan Kurniawansyah, I. S. 2017. Menghindari Kosmetika Palsu Secara Organoleptik. Majalah Farmasetika, 2(1): 8-11.

Pangaribuan, L. 2017. Efek Samping Kosmetika dan Penanganannya bagi Kaum Perempuan, Jurnal Keluarga Sehat Sejahtera. 15(2).

Pauwels, M., dan Rogiers, V. 2010. Human health safety evaluation of cosmetics in the EU: a legally imposed challenge to science. Toxicology and applied pharmacology, 243(2): 260-274.

Pereira, X.J. dan Pereira, C.T., 2018. Cosmetics and its Health Risks. Global Journal of Medical Research. 63-70. 10.34257/GJMRBVOL18IS2PG63.

Rubianti, M. A., dan Prakoeswa, C. R. S. 2019. Profil Pasien Dermatitis Kontak Alergi Akibat Kosmetik. Berkala Ilmu Kesehatan Kulit dan Kelamin, 31(1): 35-40.

Sukristiani, D., Hayatunnufus, H., dan Yuliana, Y. 2014. Pengetahuan Tentang Kosmetika Perawatan Kulit Wajah Dan Riasan Pada Mahasiswi Jurusan Kesejahteraan Keluarga Fakultas Teknik Universitas Negeri Padang. E-Journal Home Economic and Tourism, 7(3). 
Susantri, Y., Rahayu, S. W., dan Sanusi, S. 2018. Pencantuman Informasi Pada Label Produk Kosmetik Oleh Pelaku Usaha Dikaitkan Dengan Hak Konsumen. Syiah Kuala Law Journal, 2(1): 113-131. 